\title{
Recurrent Aphthous Stomatitis: Towards Evidence-Based Treatment?
}

\author{
Stephen J. Challacombe ${ }^{1}$ - Surab Alsahaf ${ }^{1}$ - Anwar Tappuni ${ }^{2}$
}

Published online: 14 July 2015

(C) Springer International Publishing AG 2015

\begin{abstract}
Recurrent aphthous stomatitis is one of the most common oral mucosal diseases seen by dental professionals, and yet its aetiology remains unclear, and its management based on less than robust evidence. The literature remains confused because of the lack of clarity in diagnosis and the lack of a standardised ulcer severity scoring system and agreed outcome measures. However, recent literature is encouraging in meeting these aims. There is agreement that recurrent aphthous stomatitis (RAS) is a localized mucosal disease not secondary to systemic disease and therefore distinguishable from over 40 other types of oral ulcers. Disease severity scores have been introduced and outcome measures have become more standardised. RAS appears to be an autoimmune disease directed at epitopes of heat shock proteins whilst most recent work on aetiology has focused on cytokines and genetics. Pro-inflammatory cytokines including TNF-a and IL-6 and IL-17 are raised in RAS and TNF inhibitors can inhibit episodes of ulceration. Many local antiinflammatory agents will help ulcers heal, and local steroids remain the treatment of choice. Some systemic drugs have evidence-based data indicating efficacy at preventing new ulcers including colchicine, prednisolone, thalidomide, pentoxyfilline and dapsone. The field would benefit from
\end{abstract}

This article is part of the Topical Collection on Oral Medicine

Stephen J. Challacombe

stephen.challacombe@kcl.ac.uk

1 Department of Oral Medicine, King's College London Dental Institute, Guys Hospital London, London SE1 9RT, UK

2 Department of Oral Medicine, Barts and the London School of Medicine and Dentistry, Queen Mary University of London, London, UK further trials combining local and systemic therapy using defined outcome measures.

Keywords Recurrent aphthous stomatitis - Oral ulceration · Interleukins $\cdot$ Steroids $\cdot$ Colchicine $\cdot$ Levamisole . Thalidomide $\cdot$ Azathioprine $\cdot$ Disease severity scores

\section{Introduction}

\section{Diagnosis}

The correct diagnosis of recurrent aphthous stomatitis (RAS, sometimes also referred to as recurrent oral ulceration or canker sores) is central to oral medicine. There are over 40 types of mouth ulcers, many related to systemic diseases, but RAS is characterised by oral ulcers, occurring singly or in crops that usually last for 7 to 21 days before healing spontaneously. These ulcers recur after a variable period, which may be a few days or several weeks. RAS can be separated clinically into three types: minor aphthous ulcers (MiAU), major aphthous ulcers (MjAU) and herpetiform ulcers (HU) (see Table 1). There has been a tendency for clinicians to describe any ulcer occurring in the mouth as aphthous. However, aphthous ulcers have been carefully defined to allow differentiation from the many other types of recurrent ulcers occurring in the oral cavity and are not associated with systemic abnormalities [1].

\section{Prevalence of RAS}

Wild overestimates of the prevalence abound, but if RAS is defined as more than two spontaneously occurring episodes per year, then an average prevalence in the population of 
Table 1 Differential types of recurrent oral ulceration and major groups of persistent oral ulceration (modified from [1])

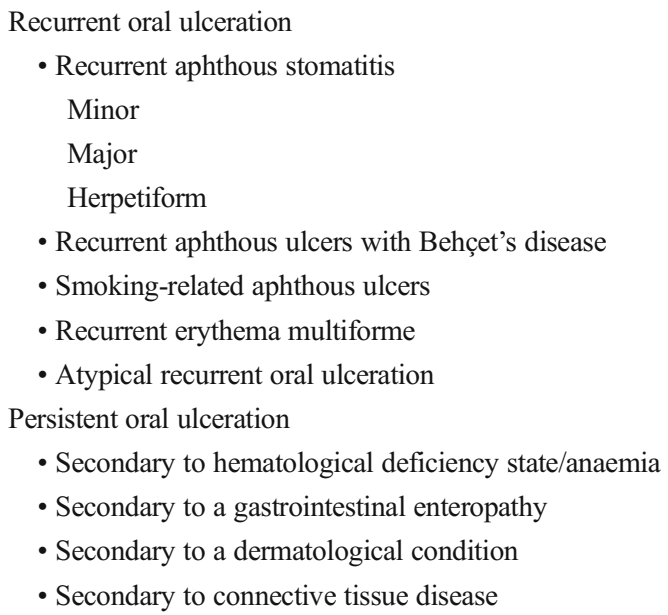

around $10 \%$ appears reasonable. Many studies struggle with definitions and ask whether subjects ever get mouth ulcers. It is likely that such studies give a prevalence much greater than those adhering to the RAS definition. Reported estimates vary between 1.5 and $28 \%$ in different parts of the world, suggesting that there may be genetic differences to account for these geographical variances [2-4]. The prevalence in children may be greater than adults $[5,6]$

\section{Aetiology}

An impressive array of factors has been implicated in the aetiology of RAS, although it is likely that many of them influence the nature of the disease rather than cause it. These include hereditary factors, hypersensitivity predisposition, socioeconomic status, psychological factors, endocrine factors, microbial agents and chemical factors in foods. There is no evidence that food allergy is causative in RAS, although it is likely that food allergy can initiate some cases of oral ulceration which might in the unwary appear to mimic RAS. Hematological deficiencies may cause some types of oral ulceration but may also influence susceptibility to other types of ulceration. In addition, lesions clinically consistent with RAS are found in association with some systemic or multisystem illnesses such as Behçet's syndrome, clinical neutropenia, vita$\min \mathrm{B}_{12}$ deficiency and celiac disease. RAS is thus best defined as being recurrent oral ulceration in the absence of known systemic factors (Table 1).

Some studies have reported an association between RAS and a variety of psychological factors including anxiety, stress and depression [7-10], but salivary cortisol levels are often normal in RAS patients even during the active phase [11]. Nevertheless, the concept of initiation of RAS through expression of heat shock (stress) proteins (Hsp) such as during viral illnesses and RAS reoccurrences when patients under stress with possible re-expression of Hsp does relate well to the evidence of reactivity of RAS patients to epitopes of Hsps (see below).

\section{Genetic Aspects}

A family history of ulcers is found in approximately $40 \%$ of patients, and the highest incidence is found in siblings of parents both of whom have RAS. Identical twins show a $90 \%$ concordance, implicating a genetic component [12]. The prevalence of human leukocyte antigens HLA-A2 and B12 (B44 subtype) was higher in RAS patients than in controls, suggesting that major histocompatibility complex (MHC) class 1 gene products may be associated [13], but it is likely that genes other than those associated with HLA may be more closely linked. Genome-wide association studies (GWAS) have not yet borne fruit, possibly because of the heterogeneity of RAS and sometimes inconsistency in diagnosis.

A number of recent studies have examined polymorphisms of individual genes in factors thought to be associated with the pathogenesis of RAS. Single nucleotide polymorphisms (SNPs) of IL-10 gene (C/A-1082, C/T-819 and C/A-592) were significantly higher in RAS patients [14]. Polymorphisms of IL-1beta and TNF-alpha production were associated with an increased risk of RAS development [15]. Genotypes of IL-6 gene $-572 \mathrm{G}>\mathrm{C}$ and $-174 \mathrm{G}>\mathrm{C}$ polymorphisms were found to be significantly higher in 184 Turkish RAS subjects [16]. Matrix metalloproteinase (MMP-9) polymorphisms have been described in RAS patients [17], and a mutation of methylene tetrahydrofolate reductase (MTHFR) gene C677T related slightly curiously with the number of oral ulcers in RAS patients [18].

These findings taken together suggest that gene abnormalities may be associated with susceptibility to RAS and that it is likely that susceptibility is related to a number of abnormalities. The relevance of such studies would be greatly enhanced if there was further understanding of the actual mechanisms and pathways leading to RAS.

\section{Immunopathogenesis}

The exact pathogenesis of RAS, a common mucosal disorder, is still unknown. A role for autoimmunity in RAS was first suggested in the 1960s [19]. Although no definitive infective microorganism has been identified, a currently accepted hypothesis is that patients are exposed to an unidentified infective or other agent, which, in susceptible patients, triggers release from normal suppression of an auto-immune response against oral mucosa. The agent is thus either in, or cross-reacts 
with, oral mucosa in these patients. Autoantibodies, cytotoxic lymphocytes and circulating lymphocytes sensitized to oral mucosa have been demonstrated in RAS patients. In most RAS patients, anti-epithelial antibodies, which are cytotoxic to oral epithelial cells, can be found [20].

A potential cross-reacting agent is heat shock protein (Hsp). Hasan et al. [21•] showed that T lymphocytes from patients with RAS recognised a unique peptide sequence of the mycobacterial Hsp 65 antigen. Responses to a human $60-\mathrm{kDa}$ Hsp peptide 116-130 were also raised. This finding suggests that RAS might be initiated by the microbial Hsp peptide, which stimulates the mucosal Langerhans cells to generate autoreactive $\mathrm{T}$ cell clones primed to the homologous peptide. The specific peptide epitope $91-105$ of the $65-\mathrm{kDa}$ mycobacterial Hsp against which RAS patients react has been identified [22]. This concept that Hsp peptides contribute to RAS pathogenesis is strengthened by the demonstration that patients with Behcets syndrome react to a different peptide, and that in animal models, immunization with this peptide leads to a form of Behcets syndrome [23.] which can be blocked by inducing oral tolerance in models or in patients with Behcets [23•].

Others have suggested that TLR2 (Toll-like receptor) stimulating peripheral blood mononuclear cells could be involved in the pathogenesis of RAS [24]. TLRs are a group of membrane receptors which can recognise molecules derived from bacteria, viruses and fungi that are involved in both immune regulation and control of epithelial barrier integrity. The hypothesis suggests that RAS occurs due to an imbalance of Th1/Th2 immune response as well as epithelial barrier dysfunction of the oral mucosa caused by impairment of TLR 2 pathways, which permitted the contact of immune competent cells from the lamina propria with oral antigens that are rich in Th1 cytokines and that will influence the onset of RAS [24, 25].

RAS is characterised histopathologically by a marked inflammatory infiltrate that initially consists predominantly of lymphocytes which then becomes mixed with neutrophils as the lesion develops [26] and adjacent keratinocytes become HLA-DR (an MHC class II cell surface receptor) and ICAM-1 (intercellular adhesion molecule-1) positive [27, 28]. Activated endothelial cells expressing adhesion molecules including ICAM-1, vascular adhesion molecule1 (VCAM-1) and E-selectin could become the target for the cytotoxic damage. The early expression of ICAM-1 by keratinocytes could be important in the early recruitment of lymphocytes. This interaction between keratinocytes and $\mathrm{CD} 8^{+}$cytotoxic $\mathrm{T}$ cells binding with ICAM-1 of keratinocytes could be responsible for the epithelium destruction and ulcer formation at the site [28]. The predominance of $\mathrm{CD}^{+}$cytotoxic $\mathrm{T}$ cells in the ulcerative stage has been demonstrated [27, 28].

\section{The Role of Oral Flora}

These theories of pathogenesis suggest that the oral flora and the host-pathogen interface are important components in the aetiology of RAS and have stimulated new study of both. Early studies had suggested that L-forms of bacteria (those without a cell wall), mycoplasma, lactobacilli or species of streptococci might be carrying the offending cross-reacting antigen.

Using DNA analysis, the microbiota of the non-inflamed buccal mucosa in RAS appears to differ between patients and controls, especially if lesions were present. This suggested that a disturbance in the normal buccal microbiota triggers the presence of lesions or that presence of lesions alters the microbiota [29, 30]. Using high-throughput 16S rRNA gene sequencing, mucosal microbiome changes in mucosae of patients with RAS were demonstrated, including increased Bacteroidales species [31]. Several studies have suggested the possible involvement of Helicobacter pylori infection in individuals with RAS, but the relationship remains controversial. A recent meta-analysis by Li et al. [32] supports the weak association between RAS and $H$. pylori infection (30\% in RAS versus $20 \%$ in controls) and suggests that in a minority of patients, $H$. pylori eradication might be of clinical benefit.

Analysing current oral flora in patients who have a history of RAS seems unlikely to determine a triggering role of a specific microbial species, but may shed light on perturbations associated with RAS.

\section{Role of Cytokines in RAS}

Cytokines are crucial mediators of immune reactivity and have been a major focus in the immunopathogenesis of RAS. Current evidence suggests that RAS may result from an abnormal cytokine cascade in the oral mucosa that leads to a cell-mediated immune response directed towards focal area of the oral mucosa [33]. There are two types of cytokines: pro-inflammatory cytokines that induces cell-mediated immunity and produced by Th1 (IL-2, IL-12, IFN-g and TNF-a) and anti-inflammatory cytokines (IL-4, IL-5, IL-10 and IL-13) produced by Th2 and promote humoral immunity and suppression of cell-mediated immunity. The imbalance of Th1/ Th2 immune response is strongly influenced by their cytokine environment $[33,34]$. The predominance of pro-inflammatory cytokines (IL-2, IL-12 TNF-a and IFN-g) in lesional biopsies of RAS patients were demonstrated in several studies $[33,35]$. Type 1 pro-inflammatory cytokines like interleukin-2 (IL-2), 
interleukin-12 (IL-12), interferon-gamma (IFN-g) and tumour necrosis factor-alpha (TNF-a) have been suggested to be implicated in the aetiopathogenesis of RAS [34].

Tumour necrosis factor alpha (TNF-a) is an important inflammatory mediator and critical cytokine for adequate host defences and because it can have direct toxic effects on epithelial cells is a clear candidate for damage in RAS as well as protection in general. TNF-a is thought to play a major role in the activation of the inflammatory process in RAS by its effect on endothelial cells adhesion molecules and its chemotactic effect on neutrophils [36]. A direct role for TNF-a in RAS is suggested by the efficacy of medications which inhibit TNF including thalidomide and pentoxifylline [37•, 38•] and infliximab [39]. Serum TNF, presumably reflecting local production, has been reported as raised in a third of patients with RAS, and related both to disease severity and stage of RAS [40] but findings were not confirmed in all studies [37•]. However, salivary TNF-a levels were reported as raised in both ulcerative and remission stages of RAS [41], and in the ulcer phase [42].

IL-6 is a multifunctional pro-inflammatory cytokine produced by macrophages, lymphocytes, keratinocytes, fibroblasts and endothelial cells in response to a variety of external stimuli. Raised serum concentrations of IL- 6 and IL- 8 were found in 25 and $60 \%$ of RAS respectively and in both major and minor types $[43 \cdot, 44,45]$ suggesting that serum IL-8 may be a more sensitive marker than IL-6 in monitoring disease activity of RAS. Other studies have not found significant differences in levels of IL-6 in serum [46] or in saliva [41].

IL-8 is a chemokine produced by keratinocytes, macrophages, mast cells and endothelial cells. It is known as neutrophil chemotactic factor. Keratinocytes in the pre-ulcerative stage of RAS may produce a significant level of IL- 8 which in turn activate neutrophils and attract cytotoxic T cells. Sun et al. [44] found that serum concentrations of IL- 8 were raised in RAS patients and significantly increased levels of serum IL-8 are found in Behcet's disease patients associated with recurrent oral ulcers $[46,47]$.

Recently, a newer subset of Th17 lymphocytes producing IL-17 was described in relation to mucosal diseases. The main function of Th17 cells is thought to be their ability to recruit neutrophils and increase the production of cytokines and chemokines by epithelial cells. Serum levels of IFN-g and IL-17 were significantly increased in RAS patients [48]. Human oral keratinocytes can produce IL-17 and stimulate the production of IL-8 and TNF-a in RAS patients compared with healthy controls [49].

Overall, there seems to be sufficient evidence to suggest that pro-inflammatory cytokines may be associated with RAS activity.

\section{Assessing Ulcer Severity}

The need for a standardised method for assessing ulcer severity and its use in determining treatment responses has long been recognised. However, authors have used such a variety of outcome measures that a Cochrane review of RAS treatment was not possible [50]. However, recently, Tappuni et al. [51•] have reported an ulcer severity scoring system which converts RAS characteristics of number of ulcers, size, duration, length of ulcer free period, site affected and pain score into numerical values out of 10 and combined to give a total out of 60. Its use has been demonstrated in a study on the efficacy of betnesol mouthwashes and systemic colchicine in RAS treatment [51•]. This Ulcer Severity Score (USS) scoring system aided in monitoring the progress of the condition, helped in assessing the efficacy of any treatment and in the management of the ulcers as well as being easy to use. An example of sequential scores in major RAS patients using colchicine is shown (see Fig. 1)

Studies measuring the effect of RAS on quality of life have been reported [53]. The Oral Health Related Quality of Life (OHR-QoL) score of RAS patients provided an additional dimension which may help to improve the impact of RAS on an individual's life. Oral Health Impact Profile (OHIP-14) measured the degree of RAS impact on functional limitation, pain, psychological discomfort, physical disability, psychological disability, social disability and handicap. Improvement after treatment with colchicine was found and thus provides a patient based assessment of the effectiveness of treatment [53].

\section{Management of RAS}

There are no internationally accepted guidelines for RAS treatment despite RAS being one of the most common oral disorders. Apart from the relief of pain, there are two main therapeutic approaches (a) to help heal current ulcers and (b) to prevent new episodes of ulceration. Many topical preparations attempt to help the healing process and many have claimed efficacy, whilst prevention of new occurrences usually requires systemic medications.

\section{Topical Therapies}

Steroid tablets used as a mouthwash are one of the most common treatments used in specialised clinics. It is a recognised therapy for RAS and generally accepted as effective in controlling this common oral condition [54], despite the limited clinical evidence to support its efficacy.

Betnesol mouthwash is a betamethasone sodium phosphate tablet $500 \mathrm{mcg}$ dissolved in $10 \mathrm{ml}$ of water and used as a mouthwash for 3 min then discarded. It is administered four 
Fig. 1 Ulcer severity scores of individual major RAS patients $(n=10)$ who were treated with colchicine $0.5 \mathrm{mg} /$ day for 12 months and then $1 \mathrm{mg} /$ day for 6 months. USS ulcer severity score [51•]. Arrows indicate times of drug administration. (modified from Alsahaf S [52])
10 major RAS patients treated with Colchicine $0.5 \mathrm{mg} /$ day for 12 months then $1 \mathrm{mg} /$ day for further 6 months

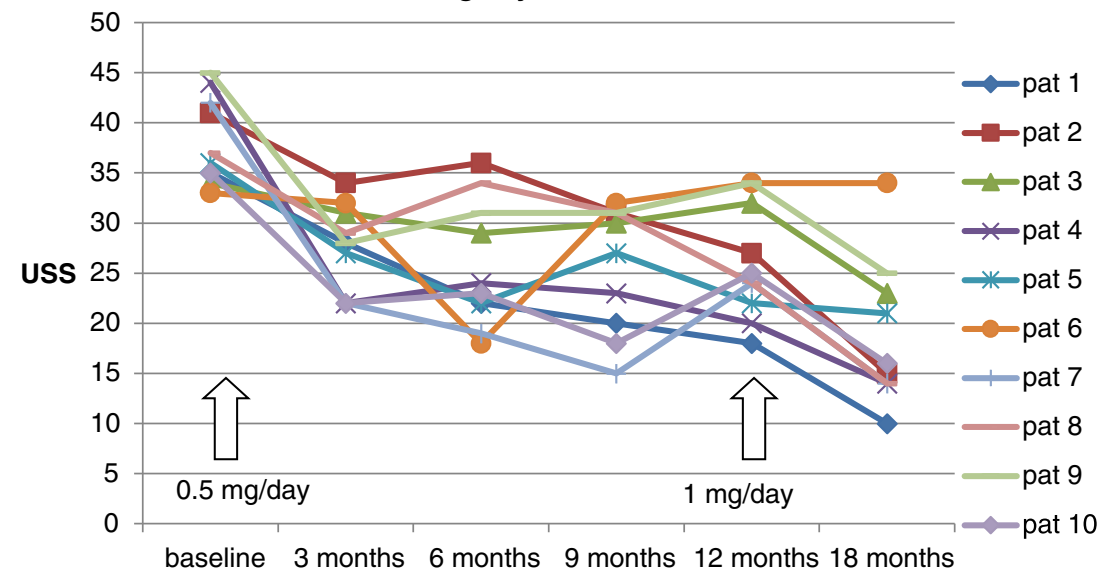

times a day (QID) in the presence of ulcers and twice a day (BID) in between ulcer attacks [1] A 3-month study by Tappuni et al. [51•] compared betnesol mouthwash (four times a day) with betnesol mouthwash plus colchicine tablets $0.5 \mathrm{mg}$ a day. Using an ulcer severity scoring (USS) system, the authors showed significant improvement in USS of most patients in the betnesol group, as well as in the combined treatment of colchicine plus betnesol.

A wide range of topical therapies have been used in the treatment of RAS but there are very few published randomised clinical trials to support their efficacy. Not all are available worldwide. Dexamethasone ointment applied three times a day for 5 days can reduce ulcer size and pain alongside an improvement in healing time [55]. Dexamucobase was at least as effective as triamcinolone acetonide in Orabase in improving healing time [56]. Amlexanox is an anti-inflammatory, anti-allergic and immunomodulatory (not currently available in the USA). Two reasonably sized double-blind trials (100200 RAS patients) showed that Amlexanox oral adhesive tablets applied 4 times a day for 5 days were effective at promoting healing and reducing pain $[57,58]$

Topical tetracycline mouthwash has been used alone or in combination with liquid anti-fungals or topical steroids, especially in the treatment of Herpetiform RAS and remains the treatment of choice in this type of RAS which appears largely resistant to steroids [59]. In major and minor RAS, topical tetracycline or minocycline mouthwashes as a local anti-bacterial can be expected to reduce the severity of the ulcerations and pain but not prevent recurrences [60,61]. Similar effectiveness in promoting healing and reducing pain has been reported with penicillin $G$ mouthwashes [62].

Several topical herbal treatments have shown efficacy as alternative therapies including aloe vera gel [63], berberine gelatine [64], Yunnan baiyao [65], Myrtus communis [66] and citrus oil with magnesium salts [67]. All of these topical herbal therapies have been used for the treatment of minor RAS only. Lalla et al. [68] demonstrated in a randomised, placebo-controlled, double-masked, parallel-arm, clinical trial that daily multivitamin supplements did not improve the number or duration of RAS episodes in 160 subjects.

\section{Systemic Therapies}

The main goals of systemic therapies are to reduce the frequency of recurrences and to minimise the duration of ulcers. Systemic immunomodulatory medications have therefore been tried for the treatment and management of severe and constantly recurring RAS, including systemic prednisolone [69], dapsone [70], levamisole [71], azathioprine [72], pentoxifylline $[37 \bullet]$, colchicine $[51 \bullet, 73]$ and thalidomide [38•] (see Table 2). These may produce remission or reduction in symptoms but all have side effects. Therefore, the treatment choices should be guided by the severity of the RAS and the potential adverse effect of medications.

Azathioprine is an immunosuppressive drug which belongs to the chemical class of purine analogues and is used in treatment of auto-immune diseases. One in 500 patients has a genetic deficiency of the enzyme thiopurine methyltransferase (TPMT) which metabolises azathioprine so assay is mandatory. There are very few published studies using azathioprine for the management of RAS; it has been used more in the treatment of Behcet's disease. Azathioprine $25 \mathrm{mg} /$ day was found to be an effective therapy in the management of oral and genital ulcerations, uveitis and arthritis in 73 patients with $\mathrm{BD}$ [73] and at $2.5 \mathrm{mg} / \mathrm{kg}$ very effective in controlling uveitis [85].

Thalidomide is an anti-TNF-a therapy which was first marketed as a sedative medication in 1957. Afterwards, thalidomide was used for the treatment of nausea and 
Table 2 Examples of systemic treatment of RAS

\begin{tabular}{|c|c|c|c|}
\hline Treatment & Results & Comments & Authors \\
\hline $\begin{array}{l}\text { Levamisole } \\
50 \mathrm{mg} / \mathrm{TDS}\end{array}$ & $\begin{array}{l}\text { Reduction in } \\
\text { ulcers in up } \\
\text { to } 66 \%\end{array}$ & $\begin{array}{l}\text { Levamisole } \\
\text { alone } \\
\text { effective } \\
\text { mode of } \\
\text { therapy }\end{array}$ & $\begin{array}{r}{[40,47} \\
71,72 \\
74-76]\end{array}$ \\
\hline $\begin{array}{l}\text { Infliximab, } \\
\text { Adalimumab, } \\
\text { Golimumab }\end{array}$ & $\begin{array}{l}\text { Complete remission } \\
\text { in up to } 89 \%\end{array}$ & $\begin{array}{l}\text { Long-term } \\
\text { expensive } \\
25 \% \text { side } \\
\text { effects }\end{array}$ & {$[77]$} \\
\hline $\begin{array}{c}\text { Dapsone } 50- \\
125 \mathrm{mg}\end{array}$ & Improvement in $60 \%$ & $\begin{array}{l}\text { Gastric side } \\
\text { effects in } \\
25 \%\end{array}$ & {$[70,78]$} \\
\hline $\begin{array}{l}\text { Colchicine } \\
500 \mu \mathrm{g} / \text { day }\end{array}$ & Effective in over $70 \%$ & $\begin{array}{l}\text { Gastric side } \\
\text { effects at } \\
\text { higher } \\
\text { doses }\end{array}$ & [78-83] \\
\hline $\begin{array}{l}\text { Prednisolone } \\
25 \mathrm{mg} / \text { day }\end{array}$ & $\begin{array}{l}\text { Pain, ulcer number } \\
\text { and duration reduced }\end{array}$ & $\begin{array}{l}2 \text { months } \\
\text { Not } \\
\text { for long } \\
\text { term }\end{array}$ & $\begin{array}{c}{[69,72,} \\
84]\end{array}$ \\
\hline $\begin{array}{l}\text { Azathioprine } \\
25 \mathrm{mg} / \text { day }\end{array}$ & $\begin{array}{l}\text { Reduction of RAS in } \\
\text { Behcets (see Table 1) }\end{array}$ & $\begin{array}{c}\text { Effective in } \\
\text { Behcets. } \\
\text { Perform } \\
\text { TPMT } \\
\text { assay }\end{array}$ & {$[73,85]$} \\
\hline $\begin{array}{l}\text { Thalidomide } \\
50 \mathrm{mg} / \text { day }\end{array}$ & $\begin{array}{l}\text { Complete remission } \\
\text { in } 85 \% \text {. Beware side } \\
\text { effects of neuropathy }\end{array}$ & $\begin{array}{l}3 \text { months } \\
\text { minimum }\end{array}$ & $\begin{array}{c}{[38 \cdot, 86} \\
87]\end{array}$ \\
\hline $\begin{array}{l}\text { Tetracycline } \\
\text { mouthwash } \\
\text { four times } \\
\text { daily }\end{array}$ & $\begin{array}{l}\text { Remission in majority } \\
\text { but not all }\end{array}$ & $\begin{array}{l}\text { Herpetiform } \\
\text { RAS }\end{array}$ & [59-61] \\
\hline $\begin{array}{l}\text { Pentoxifylline } \\
\quad 400 \mathrm{mg} / \mathrm{TDS}\end{array}$ & $\begin{array}{l}\text { Ulcer pain, size, number } \\
\text { reduced. ulcer free } \\
\text { period increased }\end{array}$ & $\begin{array}{l}2 \text { months } \\
\text { minimum }\end{array}$ & {$[37 \bullet]$} \\
\hline
\end{tabular}

TPMT Thiopurine methyltransferase

morning sickness in pregnant women but soon became infamous for its teratogenicity. This led to the establishment of more structured regulations and control over drug uses, particularly in females. It is recommended that use of thalidomide should be accompanied by nerve conduction studies (NCS) and electromyography (EMG) every 6 months to rule out peripheral neuropathy.

Nevertheless, thalidomide is considered to be an effective therapy for the managements of major RAS, and can be considered when other treatments have failed. Complete remission in $85-90 \%$ of patients with severe RAS has been reported using thalidomide $100 \mathrm{mg}$ a day for a range of periods from 3-6 months [38•, 88]. Two open trials in patients with complex aphthosis (i.e. oral and genital ulceration not fulfilling the criteria for Behcets syndrome) showed that thalidomide could be very effective at doses from 50 to $150 \mathrm{mg}$ a day over 4 years. Peripheral neuropathy was detected in some patients [86].
Remission in complex aphthosis with low dose of thalidomide $(25 \mathrm{mg} /$ day $)$ without adverse events has also been reported [87].

Levamisole used at a dose of $50 \mathrm{mg}$ daily has been shown to be effective in reducing ulcer duration, number and frequency of recurrences [76]. Some variation in studies and not all have found uniformly positive results. Most trials are short term and longer terms are needed $[71,72,74,76]$. In some patients, the RAS actually got worse but few side effects reported [89].

Dapsone has been reported to reduce ulcer recurrences in complex aphthosis with a daily dose of $50-125 \mathrm{mg}[78,86$, 88]. The exact mechanism is thought to be due to its antineutrophilic action. However, dapsone should not be administered to patients with a glucose-6-phosphate dehydrogenase (G6PD) deficiency and regular monitoring for haemolytic anaemia and methaemoglobinaemia is essential

Colchicine is an anti-inflammatory agent that limits leukocyte activity by binding to beta-Tubulin, a cellular microtubular protein, and therefore inhibiting protein polymerization [80]. Although colchicine is generally well tolerated, the most frequent gastrointestinal adverse events include nausea, diarrhoea, vomiting and abdominal pain. Colchicine at $1.5 \mathrm{mg} /$ day over 3 months showed a significant improvement of ulcers in

Table 3 Recommended treatments in three different types of RAS

\begin{tabular}{|c|c|c|c|}
\hline & First line treatment & $\begin{array}{l}\text { Second line } \\
\text { treatment }\end{array}$ & $\begin{array}{l}\text { Maintenance } \\
\text { treatment }\end{array}$ \\
\hline Minor RAS & $\begin{array}{l}\text { For } 3 \text { months local } \\
\text { steroid } \\
\text { mouthwash four } \\
\text { times a day } \\
\text { when ulcers } \\
\text { present, twice } \\
\text { daily when not. }\end{array}$ & $\begin{array}{l}\text { Colchicine } 500-1 \\
000 \mu \mathrm{g} / \text { day } \\
\text { for } 3 \text { to } \\
6 \text { months }\end{array}$ & $\begin{array}{l}\text { Local steroid } \\
\text { mouthwash } \\
\text { four times } \\
\text { a day when } \\
\text { ulcers present }\end{array}$ \\
\hline Major RAS & $\begin{array}{l}\text { Colchicine } 500- \\
1000 \mu \mathrm{g} / \text { day for } \\
6 \text { months. } \\
\text { Short course of } \\
\text { systemic } \\
\text { steroids may } \\
\text { precede }\end{array}$ & $\begin{array}{c}\text { Azathioprine } 50- \\
100 \mathrm{mg} / \text { day }\end{array}$ & $\begin{array}{l}\text { Local steroid } \\
\text { mouthwash } \\
\text { four times } \\
\text { a day when } \\
\text { ulcers present }\end{array}$ \\
\hline $\begin{array}{l}\text { Herpetiform } \\
\text { RAS }\end{array}$ & $\begin{array}{l}\text { Tetracycline } \\
\text { mouthwashes } \\
\text { four times a day } \\
\text { when ulcers }\end{array}$ & $\begin{array}{l}\text { Colchicine } 500- \\
1000 \mu \mathrm{g} / \text { day } \\
\text { for } 3-6 \text { months }\end{array}$ & $\begin{array}{l}\text { Tetracycline } \\
\text { mouthwashes } \\
\text { four times a } \\
\text { day in } \\
\text { prodrome }\end{array}$ \\
\hline $\begin{array}{l}\text { RAS in } \\
\text { children }\end{array}$ & $\begin{array}{l}\text { Hydrocortisone } \\
\text { hemisuccinate } \\
\text { pellets } 2.5 \mathrm{mg} \\
\text { four times daily }\end{array}$ & $\begin{array}{l}\text { Local steroid } \\
\text { mouthwash } \\
\text { four times a day } \\
\text { when ulcers } \\
\text { present }\end{array}$ & $\begin{array}{l}\text { Continue for } \\
3 \text { months, } \\
\text { twice daily } \\
\text { if no ulcers }\end{array}$ \\
\hline
\end{tabular}

Effectiveness of treatment to be monitored in every patient by use of Ulcer Severity Score [51•] and OHIP quality of life score [53]. There is not as yet an evidence based consensus for protocols 
over two thirds of patients $[79,81,82]$, but over $25 \%$ of patients reported side effects, mainly abdominal pain [81]. Similar results have been reported in other trials with $1.8 \mathrm{mg} /$ day showing effectiveness in complex aphthosis but a high rate of side effects [78]. Colchicine has been shown to be safe with a low dose of $0.5-1 \mathrm{mg}$ a day in children aged 3.5-11 years old with periodic fever, aphthous stomatitis, pharyngitis and adenitis disease (PFAPA) [83].

Lower doses $(500 \mu \mathrm{g} /$ day $)$ appear effective when combined with topical steroids for 3 months [51•]. These findings suggested that in the short-term, topical steroids improved ulcer symptoms, whilst colchicine seemed to prevent recurrences. This study used an Ulcer Severity Score (USS) (see above). A comparison of prednisolone $5 \mathrm{mg}$ /day or colchicine $0.5 \mathrm{mg}$ /day for 3 months in a double-blind clinical trial of RAS showed effectiveness of both modalities of treatments. Adverse events were reported in colchicine group (52.9\%) compared to $11.8 \%$ in the prednisolone group [69].

\section{Other Treatments of RAS}

The use of intra-lesional injections of steroids in severe cases of RAS with large single ulcers affecting quality of life such as eating, talking and swallowing, can be considered. Immediate relief of pain and a significant improvement in healing time with a single session of Carbon dioxide $\left(\mathrm{CO}_{2}\right)$ laser treatment in patients with minor RAS has been reported in randomised controlled trials $[90,91]$. More recently, Botulinum toxin has been reported as effective [92]. However, they are directed at healing current ulcers, and concurrent systemic treatment is usually needed for prevention of new ulcers

\section{Conclusions}

A variety of treatments for RAS abound in oral medicine, but even with what have become standard therapies such as local steroids, there are few clinical trials. The failure to standardize clinical diagnoses and the failure to have robust clinical severity scores for RAS has lead to reporting a variety of clinical outcomes. The use of an ulcer severity score should allow both the severity of the entry of patients with RAS to be compared, but also the effectiveness of treatments to be followed on a routine basis. The recent report that an evidence-based review of treatments was not possible because of the variety of outcomes used, emphasises the need for agreed outcome measures.

A second issue in the literature is the failure to clearly distinguish between treatments designed to heal current ulcers and the much more difficult challenge of preventing new ulcer episodes. Almost any anti-bacterial agent, or antiinflammatory agent, can be expected to aid healing and pain, but few would be expected to prevent new ulcers episodes. Local steroid mouthwashes appear to be efficacious and the topical therapy of first choice, and there is evidence that local steroid mouthwashes can reduce the ulcer frequency as well as aid healing of current ulcers.

Prevention of new ulcers normally requires systemic therapy. There was strong evidence in the majority of the studies that supported the efficacy and safety of colchicine in the management of RAS in spite of a high proportion of gastric upsets at the doses used. However, the majority of the studies were for a short period (3-6 months) and there was a lack of a randomised clinical trial with a good sample size. Thalidomide demonstrated conclusive benefits with a dose of 50 $150 \mathrm{mg} /$ day in the managements of major RAS, but should not be a treatment of first choice. Azathioprine is relatively untried in major RAS and would not seem to be the agent of first choice in minor RAS. Pentoxifylline and dapsone appear worthy of further trials for efficacy. A suggested protocol is seen in Table 3.

\section{Compliance with Ethics Guidelines}

Conflict of Interest Stephen J Challacombe, Surab Alsahaf and Anwar Tappuni declare that they have no conflict of interest.

Human and Animal Rights and Informed Consent This article does not contain any studies with human or animal subjects performed by any of the authors

\section{References}

Papers of particular interest, published recently, have been highlighted as:

- Of importance

1. Challacombe SJ, Shirlaw PJ. Oral ulceration: when to treat refer or ignore. Dent Update. 1991;52:368-73.

2. Patil S, Reddy SN, Maheshwari S, Khandelwal S, Shruthi D, Doni B. Prevalence of recurrent aphthous ulceration in the Indian Population. J Clin Exp Dent. 2014;6(1):36-40.

3. Abdullah MJ. Prevalence of recurrent aphthous ulceration experience in patients attending Piramird dental speciality in Sulaimani City. J Clin Exp Dent. 2013;5(2):89-94.

4. Bhatnagar P, Rai S, Bhatnagar G, Kaur M, Goel S, Prabhat M. Prevalence study of oral mucosal lesions, mucosal variants, and treatment required for patients reporting to a dental school in North India: In accordance with WHO guidelines. J Fam Community Med. 2013;20(1):41-8.

5. Majorana A, Bardellini E, Flocchini P, Amadori F, Conti G, Campus G. Oral mucosal lesions in children from 0 to 12 years old: ten years' experience. Oral Surg Oral Med Oral Pathol Oral Radiol Endod. 2010;110(1):13-8. 
6. Krisdapong S, Sheiham A, Tsakos G. Impacts of recurrent aphthous stomatitis on quality of life of 12- and 15-year-old Thai children. Qual Life Res. 2012;21(1):71-6.

7. Bagan J, Saez G, Tormos C, Gavalda C, Sanchis JM, Bagan L, et al. Oxidative stress and recurrent aphthous stomatitis. Clin Oral Investig. 2014;18(8):1919-23.

8. Keenan AV, Spivakovksy S. Stress associated with onset of recurrent aphthous stomatitis. Evid Based Dent. 2013;14(1):25.

9. Alshahrani S, Baccaglini L. Psychological screening test results for stress, depression, and anxiety are variably associated with clinical severity of recurrent aphthous stomatitis and oral lichen planus. J Evid Based Dent Pract. 2014;14(4):206-8.

10. Al-Omiri MK, Karasneh J, Lynch E. Psychological profiles in patients with recurrent aphthous ulcers. Int J Oral Maxillofac Surg. 2012;41(3):384-8.

11. Eguia-del Valle A, Martínez-Conde-Llamosas R, López-Vicente J, Uribarri-Etxebarria A, Aguirre-Urizar JM. Salivary cortisol determination in patients from the Basque Country with recurrent aphthous stomatitis. A pilot study. Med Oral Patol Oral Cir Bucal. 2013;18(2):e207-11.

12. Miller MF, Garfunkel AA, Ram C, Ship II. Inheritance patterns in recurrent aphthous ulcers: twin and pedigree data. Oral Surg Oral Med Oral Pathol. 1977;43(6):886-91.

13. Challacombe SJ, Batchelor JR, Kennedy LA, Lehner T. HLA antigens in recurrent oral ulceration. Arch Dermatol. 1977;113:1717-9.

14. Najafi S, Firooze Moqadam I, Mohammadzadeh M, Bidoki AZ, Yousefi $\mathrm{H}$, Farhadi E, et al. Interleukin-10 gene polymorphisms in recurrent aphthous stomatitis. Immunol Invest. 2014;43(4):405-9.

15. Guimarães AL, Correia-Silva F, Sá AR, Victória JM, Diniz MG, Costa $\mathrm{O}$, et al. Investigation of functional gene polymorphisms IL1 beta, IL-6, IL-10 and TNF-alpha in individuals with recurrent aphthous stomatitis. Arch Oral Biol. 2007;52(3):268-72.

16. Karakus N, Yigit S, Rustemoglu A, Kalkan G, Bozkurt N. Effects of interleukin (IL)-6 gene polymorphisms on recurrent aphthous stomatitis. Arch Dermatol Res. 2014;306(2):173-80.

17. Karasneh JA, Bani-Hani ME, Alkhateeb AM, Hassan AF, Thornhill MH. Association of MMP but not TIMP-1 gene polymorphisms with recurrent aphthous stomatitis. Oral Dis. 2014;20(7):693-9.

18. Kalkan G, Karakus N, Yigit S. Association of MTHFR gene C677T mutation with recurrent aphthous stomatitis and number of oral ulcers. Clin Oral Investig. 2014;18(2):437-41.

19. Lehner T. Autoimmunity in oral diseases, with special reference to recurrent oral ulceration. Proc R Soc Med. 1968;61(5):515-24.

20. Thomas DW, Bagg J, Walker DM. Characterization of the effector cells responsible for the in vitro cytotoxicity of blood leukocytes from aphthous ulcer patients for oral epithelial cells. Gut. 1990;31: 294-9.

21. Hasan A, Childerstone A, Pervin K, Shinnick T, Mizushima Y, Van Der Zee R, et al. Recognition of a unique peptide epitope of the mycobacterial and human heat shock protein 65-60 antigen by $T$ cells of patients with recurrent oral ulcers. Clin Exp Immunol. 1995;99(3):392-7. Recommended paper.

22. Hasan A, Shinnick T, Mizushema V, Van Der Zee R, Lehner T. Defining a T-cell epitope within HSP 65 in recurrent aphthous stomatitis. Clin Exp Immunol. 2002;128(2):318-25.

23. Phipps P-A, Stanford M-R, Sun J-B, Xiao B-G, Holmgren J, Schinnick T, et al. Prevention of mucosally induced uveitis with a HSP60-derived peptide linked to cholera toxin B subunit. Eur J Immunol. 2003;33:224-32. Recommended paper.

24. Gallo C, Barros F, Sugaya N, Nunes F, Borra R. Differential expression of toll-like receptor mRNAs in recurrent aphthous ulceration. J Oral Pathol Med. 2012;41(1):80-5.

25. Seoudi N, Bergmeier LA, Hagi-Pavli E, Bibby D, Curtis MA, Fortune F. The role of TLR 2 and 4 in Behçet's disease pathogenesis. Innate Immun. 2014;20(4):412-22.
26. Poulter LW, Lehner T. Immunohistology of oral lesions from patients with recurrent oral ulcers and Behcets syndrome. Clin Exp Immunol. 1989;78(2):189-95.

27. Savage NW, Seymour GJ, Kruger BJ. T-lymphocyte subset changes in recurrent aphthous stomatitis. Oral Surg Oral Med Oral Pathol. 1985;60(2): 175-81.

28. Healy CM, Thornhill MH. Induction of adhesion molecule expression on blood vessels and keratinocytes in recurrent oral ulceration. J Oral Pathol Med. 1999;28(1):5-11.

29. Seoudi N, Bergmeier LA, Drobniewski F, Paster B, Fortune F. The oral mucosal and salivary microbial community of Behçet's syndrome and recurrent aphthous stomatitis. J Oral Microbiol. 2015;7: 27150 .

30. Bankvall M, Sjöberg F, Gale G, Wold A, Jontell M, Östman S. The oral microbiota of patients with recurrent aphthous stomatitis. J Oral Microbiol. 2014;6:25739.

31. Hijazi K, Lowe T, Meharg C, Berry SH, Foley J, Hold GL. Mucosal microbiome in patients with recurrent aphthous stomatitis. J Dent Res. 2015;94(3 Suppl):87S-94S.

32. Li L, Gu H, Zhang G. Association between recurrent aphthous stomatitis and Helicobacter pylori infection: a meta-analysis. Clin Oral Investig. 2014;18(6):1553-60.

33. Buño IJ, Huff JC, Weston WL, Cook DT, Brice SL. Elevated levels of interferon gamma, tumor necrosis factor alpha, interleukins 2, 4, and 5, but not interleukin 10, are present in recurrent aphthous stomatitis. Arch Dermatol. 1998;134(7):827-31.

34. Lewkowicz N, Lewkowicz P, Banasik M, Kurnatowska A, Techorzewski H. Predominance of type 1 cytokines and decreased number of CD4+ CD25 +high T regulatory cells in peripheral blood of patients with recurrent aphthous ulcerations. Immunol Lett. 2005;99(1):57-62.

35. Albanidou-Farmaki E, Markopoulos AK, Kalogerakou F, Antoniades DZ. Detection, enumeration and characterization of T helper cells secreting type 1 and type 2 cytokines in patients with recurrent aphthous stomatitis. Tohoku J Exp Med. 2007;212(2): $101-5$.

36. Natah SS, Häyrinen-Immonen R, Hietanen J, Malmström M, Konttinen YT. Immunolocalization of tumor necrosis factor-alpha expressing cells in recurrent aphthous ulcer lesions (RAU). J Oral Pathol Med. 2000;29(1):19-25.

37. Thornhill MH, Baccaglini L, Theaker E, Pemberton MN. A randomized, double-blind, placebo-controlled trial of pentoxifylline for the treatment of recurrent aphthous stomatitis. Arch Dermatol. 2007;143(4):463-70. Recommended paper.

38. Hello M, Barbarot S, Bastuji-Garin S, Revuz J, Chosidow O. Use of thalidomide for severe recurrent aphthous stomatitis: a multicenter cohort analysis. Medicine (Baltimore). 2010;89(3):176-82. Recommended paper.

39. Ryu HJ, Seo MR, Choi HJ, Baek HJ. (2014) Infliximab for refractory oral ulcers. Am J Otolaryngol. 2014;35(5):664-8.

40. Sun A, Wang JT, Chia JS, Chiang CP. Levamisole can modulate the serum tumor necrosis factor-alpha level in patients with recurrent aphthous ulcerations. J Oral Pathol Med. 2006;35(2):111-6.

41. Boras VV, Lukac J, Brailo V, Picek P, Kordić D, Zilić IA. Salivary interleukin- 6 and tumor necrosis factor-alpha in patients with recurrent aphthous ulceration. J Oral Pathol Med. 2006;35(4):241-3.

42. Eguia-del Valle A, Martinez-Conde-Lamosas R, Lopez-Vicente J, Uribarri-Etxebarria A, Aguirre-Urizar JM. Salivary levels of tumour necrosis factor-alpha in patients with recurrent aphthous stomatitis. Med Oral Patol Oral Cir Bucal. 2011;16:e33-6.

43. Sun A, Chang YF, Chia JS, Chiang CP. Serum interleukin-8 level is a more sensitive marker than serum interleukin-6 level in monitoring the disease activity of recurrent aphthous ulcerations. J Oral Pathol Med. 2004;33(3):133-9. Recommended paper.

44. Sun A, Chia JS, Chang YF, Chiang CP. Levamisole and Chinese medicinal herbs can modulate the serum interleukin-6 level in 
patients with recurrent aphthous ulcerations. J Oral Pathol Med. 2003;32(4):206-14.

45. Pekiner FN, Aytugar E, Demirel GY, Borahan MO. Interleukin-2, interleukin- 6 and $T$ regulatory cells in peripheral blood of patients with Behçet's disease and recurrent aphthous ulcerations. J Oral Pathol Med. 2012;41(1):73-9.

46. Zouboulis CC, Katsantonis J, Ketteler R, Treudler R, Kaklamani E, Hornemann S, et al. Adamantiades-Behçet's disease: interleukin- 8 is increased in serum of patients with active oral and neurological manifestations and is secreted by small vessel endothelial cells. Arch Dermatol Res. 2000;292(6):279-84.

47. Gupta P, Ashok L, Naik SR. Assessment of serum interleukin-8 as a sensitive serological marker in monitoring the therapeutic effect of levamisole in recurrent aphthous ulcers: a randomized control study. Indian J Dent Res. 2014;25(3):284-9.

48. Ozyurt K, Celik A, Sayarloglu M, Colgecen E, Incı R, Karakas T, et al. Serum Th1, Th2 and Th17 cytokine profiles and alpha-enolase levels in recurrent aphthous stomatitis. J Oral Pathol Med. 2014;43(9):691-5.

49. Al-Samadi A, Kouri VP, Salem A, Ainola M, Kaivosoja E, Barreto G, et al. IL-17C and its receptor IL-17RA/IL-17RE identify human oral epithelial cell as an inflammatory cell in recurrent aphthous ulcer. J Oral Pathol Med. 2014;43(2):117-24.

50. Taylor J, Glenny AM, Walsh T, Brocklehurst P, Riley P, Gorodkin $\mathrm{R}$, et al. Interventions for the management of oral ulcers in Behçet's disease. Cochrane Database Syst Rev. 2014;9:CD011018.

51. Tappuni AR, Kovacevic T, Shirlaw PJ, Challacombe SJ. Clinical assessment of disease severity in recurrent aphthous stomatitis. J Oral Pathol Med. 2013;42(8):635-41. Recommended paper.

52. Alsahaf S. Recurrent Aphthous Stomatitis: treatment efficacy of local Betamethasone mouthwash and systemic colchicine therapy and their effect on serum and salivary cytokines. PhD thesis 2014. King's College London.

53. Hapa A, Aksoy B, Polat M, Aslan U, Atakan N. Does recurrent aphthous stomatitis affect quality of life? A prospective study with 128 patients evaluating different treatment modalities. J Dermatolog Treat. 2011;22(4):215-20.

54. Scully C, Gorsky M, Lozada-Nur F. The diagnosis and managements of recurrent aphthous ulcerations: a consensus approach. J Am Dent Assoc. 2003;134(2):200-7.

55. Liu J, Zeng X, Chen Q, Cai Y, Chen F, Wang Y, et al. An evaluation on the efficacy and safety of amlexanox oral adhesive tablets in the treatment of recurrent minor aphthous ulceration in a Chinese cohort: a randomized, double-blind, vehicle-controlled, unparallel multicenter clinical trial. Oral Surg Oral Med Oral Pathol Oral Radiol Endod. 2006;102(4):475-81.

56. Al-Na'mah ZM, Carson R, Thanoon IA. Dexamucobase: a novel treatment for oral aphthous ulceration. Quintessence Int. 2009;40(5):399-404.

57. Liu C, Zhou Z, Liu G, Wang Q, Chen J, Wang L, et al. Efficacy and safety of dexamethasone ointment on recurrent aphthous ulceration. Am J Med. 2012;125(3):292-301.

58. Meng W, Dong Y, Liu J, Wang Z, Zhong X, Chen R, et al. A clinical evaluation of amlexanox oral adhesive pellicles in the treatment of recurrent aphthous stomatitis and comparison with amlexanox oral tablets: a randomized, placebo controlled, blinded, multicenter clinical trial. Trials. 2009;10:30.

59. Graykowski EA, Kingman A. Double-blind trial of tetracycline in recurrent aphthous ulcerations. J Oral Pathol. 1978;7:376-82.

60. Gorsky M, Epstein J, Rabenstein S, Elishoov H, Yarom N. Topical minocycline and tetracycline rinses in treatment of recurrent aphthous stomatitis: a randomized cross-over study. Dermatol Online J. 2007;13(2):1.

61. Gorsky M, Epstein J, Raviv A, Yaniv R, Truelove E. Topical minocycline for managing symptoms of recurrent aphthous stomatitis. Spec Care Dentist. 2008;28(1):27-31.
62. Zhou Y, Chen Q, Meng W, Jiang L, Wang Z, Liu J, et al. Evaluation of penicillin $\mathrm{G}$ potassium troches in the treatment of minor recurrent aphthous ulceration in a Chinese cohort: a randomized, doubleblinded, placebo and no-treatment-controlled, multicenter clinical trial. Oral Surg Oral Med Oral Pathol Oral Radiol Endod. 2010;109(4):561-6.

63. Babaee N, Zabihi E, Mohseni S, Moghadamnia AA. Evaluation of the therapeutic effects of Aloe vera gel on minor recurrent aphthous stomatitis. Dent Res J (Isfahan). 2012;9:381-5.

64. Jiang XW, Zhang Y, Zhu YL, Zhang H, Lu K, Li FF, et al. Effects of berberine gelatin on recurrent aphthous stomatitis: a randomized, placebo-controlled, double-blind trial in a Chinese cohort. Oral Surg Oral Med Oral Pathol Oral Radiol. 2013;115:212-7.

65. Liu X, Guan X, Chen R, Hua H, Liu Y, Yan Z. Repurposing of yunnan baiyao as an alternative therapy for minor recurrent aphthous stomatitis. Evid Based Complement Alternat Med. 2012;2012:284620.

66. Babaee N, Mansourian A, Momen-Heravi F, Moghadamnia A, Momen-Beitollahi J. The efficacy of a paste containing Myrtus communis (Myrtle) in the management of recurrent aphthous stomatitis: a randomized controlled trial. Clin Oral Investig. 2010;14: 65-70.

67. Shemer A, Amichai B, Trau H, Nathansohn N, Mizrahi B, Domb AJ. Efficacy of a mucoadhesive patch compared with an oral solution for treatment of aphthous stomatitis. Drugs R D. 2008;9:29-35.

68. Lalla RV, Choquette LE, Feinn RS, Zawistowski H, Latortue MC, Kelly ET, et al. Multivitamin therapy for recurrent aphthous stomatitis: a randomized, double-masked, placebo-controlled trial. J Am Dent Assoc. 2012;143:370-6.

69. Pakfetrat A, Mansourian A, Momen-Heravi F, Delavarian Z, Momen-Beitollahi J, Khalilzadeh O, et al. Comparison of colchicine versus prednisolone in recurrent aphthous stomatitis: A double-blind randomized clinical trial. Clin Invest Med. 2010;33: 189-95.

70. Handfield-Jones S, Allen BR, Littlewood SM. Dapsone use in oral genital ulcers. Br J Dermatol. 1985;113:501.

71. Sun A, Chiang CP, Chiou PS, Wang JT, Liu BY, Wu YC. Immunomodulation by levamisole in patients with recurrent aphthous ulcers or oral lichen planus. J Oral Pathol Med. 1994;23:172-7.

72. Brown RS, Bottomley WK. Combination an immunosuppressant and topical steroids therapy for treatment of recurrent major aphthae. Oral Surg Oral Med Oral Pathol. 1990;69:42-4.

73. Yazici H, Pazarli H, Barnes CG, Tuzun Y, Ozyazgan Y, Silman A, et al. A controlled trial of azathioprine in Behcet's syndrome. N Engl Med. 1990;322:281-5.

74. Devi M, Ramesh D, Koppal S, Byatnal AR, Rukmangada T, Byatnal AA. Efficacy of rebamipide and levamisole in the treatment of patients with recurrent aphthous ulcer - a comparative study. J Clin Diagn Res. 2014;8(11):119-22.

75. Sun A, Wang YP, Chia JS, Liu BY, Chiang CP. Treatment with levamisole and colchicine can result in a significant reduction of IL-6, IL-8 or TNF- $\alpha$ level in patients with mucocutaneous type of Behcet's disease. J Oral Pathol Med. 2009;38(5):401-5.

76. Sharda N, Shashikanth MC, Kant P, Jain M. Levamisole and lowdose prednisolone in the treatment of reccurent aphthous stomatitis. J Oral Pathol Med. 2014;43(4):309-16.

77. Sand FL, Thomsen SF. Efficacy and safety of TNF- $\alpha$ inhibitors in refractory primary complex aphthosis: a patient series and overview of the literature. J Dermatolog Treat. 2013;24(6):444-6.

78. Lynde CB, Bruce AJ, Rogers 3rd RS. Successful treatment of complex aphthosis with colchicine and dapsone. Arch Dermatol. 2009; 145:273-6.

79. Ruah CB, Stram JR, Chasin WD. Treatment of severe recurrent aphthous stomatitis with colchicine. Arch Otolaryngol Head Neck Surg. 1988;114(6):671-5. 
80. Sullivan TP, King Jr LE, Boyd AS. Colchicine in dermatology. J Am Acad Dermatol. 1998;39(6):993-9.

81. Hassan A, Ahmed Z, Ali R, Ara F, Ahmed N, Salam MU. Colchicine in the treatment of recurrent oral aphthous ulcer-open clinical trial in Bangladesh. Bangladesh Med J. 2010;39(3):39-42.

82. Fontes V, Machet L, Huttenberger B, Lorette G, Vaillant L. Recurrent aphthous stomatitis: treatment with colchicine. An open trial of 54 cases. Ann Dermatol Venereol. 2002;129(12):1365-9.

83. Tasher D, Stein M, Dalal I, Somekh E. Colchicine prophylaxis for frequent periodic fever, aphthous stomatitis, pharyngitis and adenitis episodes. Acta Paeditr. 2008;97(8):1090-2.

84. Femiano F, Buonaiuto C, Gombos F, Lanza A, Cirillo N. Pilot study on recurrent aphthous stomatitis (RAS): a randomized placebocontrolled trial for the comparative therapeutic effects of systemic prednisone and systemic montelukast in subjects unresponsive to topical therapy. Oral Surg Oral Med Oral Pathol Oral Radiol Endod. 2010;109(3):402-7.

85. Saadoun D, Wechsler B, Terrada C, Hajage D, Le Thi Huong D, Resche-Rigon M, et al. Azathioprine in severe uveitis of Behçet's disease. Arthritis Care Res (Hoboken). 2010;62(12):1733-8.

86. Letsinger JA, McCarty MA, Jorizzo JL. Complex aphthosis: a large case series with evaluation algorithm and therapeutic ladder from topicals to thalidomide. J Am Acad Dermatol. 2005;52(3 Pt 1):500 8.

87. Gil H, Perrin S, Dupond JL, Meaux-Ruault N, Hafsaoui C, Limat S, et al. Recurrent aphthosis: safety of low dose thalidomide. Rev Med Interne. 2010;31(6):403-5.

88. Mimura MA, Hirota SK, Sugaya NN, Sanches Jr JA, Migliari DA. Systemic treatment in severe cases of recurrent aphthous stomatitis: an open trial. Clinics (Sao Paulo). 2009;64(3):193-8.

89. Lehner T, Wilton JM, Ivanyi L. Double blind crossover trial of levamisole in recurrent aphthous ulceration. Lancet. 1976;2(7992):926-9.

90. Prasad RS, Pai A. Assessment of immediate pain relief with laser treatment in recurrent aphthous stomatitis. Oral Surg Oral Med Oral Pathol Oral Radiol. 2013;116(2):189-93.

91. Zand N, Fateh M, Ataie-Fashtami L, Djavid GE, Fatemi SM, Shirkavand A. Promoting wound healing in minor recurrent aphthous stomatitis by non-thermal, non-ablative $\mathrm{CO}(2)$ laser therapy: a pilot study. Photomed Laser Surg. 2012;30(12):719-23.

92. Yang TY, Jang TY. The value of local botulinum toxin A injection in the treatment of the pain of aphthous ulcer. Eur Arch Otorhinolaryngol. 2009;266(3):445-8. 